\title{
Testing a typology system of running waters for conservation planning in Hungary
}

\author{
Dénes Schmera $\cdot$ Bruno Baur
}

Received: 3 September 2010/Revised: 31 January 2011/Accepted: 6 February 2011 / Published online: 20 February 2011

(C) Springer Science+Business Media B.V. 2011

\begin{abstract}
Landscape and site classifications are increasingly being used in conservation planning and biodiversity management. We examined the utility of a simple typology system for predicting the conservation value of running-water sites in Hungary using aquatic invertebrates. Aquatic invertebrates (444 species) were collected by kick and sweep sampling technique, in a few cases also with a net, at 317 running-water sites covering the entire area of Hungary. On the basis of three criteria (naturalness, altitude and size of catchment area) we obtained a typology scheme distinguishing five running-water types: artificial lowland stream, natural highland river, natural highland stream, natural lowland river and natural lowland stream. We expressed the conservation value of each site using the numbers of native species, unique native species, redlist species, protected species and alien species.
\end{abstract}

Handling editor: B. Oertli

D. Schmera $(\bowtie) \cdot$ B. Baur

Section of Conservation Biology, Department of Environmental Sciences, University of Basel, St. Johanns-Vorstadt 10, 4056 Basel, Switzerland e-mail: denes.schmera@unibas.ch

D. Schmera

Balaton Limnological Research Institute, Hungarian Academy of Sciences, Klebelsberg K. u. 3, Tihany 8237, Hungary
Furthermore, the conservation value of each river type was expressed by a measure of beta diversity. Our results show that any interpretation of the effect of a single criterion might be misleading. Consequently, the use of the whole typology system is recommended. The study revealed that all stream types are valuable to a certain extent because they maintain distinct biological communities. We found that the conservation value of artificial watercourses is comparable to that of natural running-water sites. We identified that natural lowland rivers and artificial lowland streams are the ones mostly exposed to species invasions. These findings are essential in maintaining and protecting conservation values of any freshwater ecosystem, and may contribute to management decisions on running waters in Hungary.

Keywords Alien species - Aquatic invertebrates · Artificial habitat · Biodiversity assessment . Conservation value $\cdot$ Running waters $\cdot$ Typology

\section{Introduction}

Freshwater ecosystems are amongst the most endangered ecosystems in the world (Dudgeon et al., 2006). Running waters suffer from water pollution, habitat degradation, climate change, flow modification, overexploitation and species invasion (Giller \& Malmqvist, 1998; Dudgeon et al., 2006; Ormerod, 2009; Wirth et al., 2010). All of these influence the 
integrity of rivers (Karr et al., 1985; Poff et al., 1997) and demand for urgent measures to conserve river biodiversity and for a deeper understanding of underlying processes shaping patterns of biodiversity. Several theories have been developed to explain patterns and processes of community organisation in running waters. It is assumed that the abiotic habitat template is the major determinant of community organisation in running waters (Hynes, 1970; Townsend, 1989; Ward, 1989; Townsend \& Hildrew, 1994; Allan, 1995). Therefore, environmental surrogates are commonly used for understanding spatial pattern of biodiversity in streams and rivers (Rabeni et al., 2002; Williams et al., 2003, Heino \& Mykra, 2006).

Recent methodological developments provided a structured, efficient and scientifically defensible framework for identifying conservation importance of river sites combining a wide array of factors with numerous measures of biodiversity (Higgins et al., 2004; Moilanen et al., 2008; Nel et al., 2009). However, in many cases, we are only interested in the conservation value of classes of river sites (e.g. what is the conservation importance of lowland rivers?), or whether a limited number of environmental surrogates reflects the variability of biodiversity. For these purposes, relatively simple typology systems are receiving increasing attention (Verdonschot \& Nijboer, 2004; Heino \& Mykra, 2006; Erős, 2007).

Typology is probably the most commonly used method of classifying rivers. By definition, typology is conceptual, based upon a priori, subjective judgement of class definitions and boundaries (Newson et al., 1998). Most typology schemes use multiple judgements (i.e. different criteria) to define runningwater types. The majority of these criteria follow geomorphological characteristics (Hawkins \& Vinson, 2000; Heino \& Mykra, 2006; Pyne et al., 2007), but ecoregional attributes, climatology, naturalness or any other criterion might also be considered (Verdonschot \& Nijboer, 2004; Sandin \& Verdonschot, 2006; Vermonden et al., 2009). River-site typologies are increasingly being used in conservation planning and biodiversity management (Hawkins et al., 2000; Erös, 2007). However, information on the contribution of individual criteria to the conservation value of particular sites is basically missing (e.g. in comparisons of the conservation value of natural vs. artificial sites, see Le Viol et al., 2009; or in comparisons of streams and rivers, see Schmera \& Kiss, 2004). It is not clear, why typology is preferred over individual criteria. Comparing single criterion (e.g. the size of the catchment area) allows a direct judgement of individual effects (e.g. whether streams or rivers are more valuable). Typology measures do not provide such detailed information. Furthermore, typology measures do not necessarily follow a full factorial design of criteria because of the nature of the data (e.g. Verdonschot \& Nijboer, 2004). Hence, we do not know whether predictions of site classification criteria are in agreement with a typology-based conservation assessment of running waters. If, for instance, site classification criteria show interactions with each other, then the use of their individual (main) effect might cause false decisions in projects focusing on biodiversity management. To avoid this, it is essential to disentangle the role of individual criteria of a typology scheme in predicting the conservation importance of sites or groups of sites.

We assessed the conservation value of runningwater sites in Hungary using several measures of aquatic invertebrates. Three environmental characteristics (naturalness, altitude and size of the catchment area) were used as criteria in these assessments. In particular, we addressed the following questions: (1) how does an individual criterion predict the conservation value of aquatic invertebrates in running-water sites, and (2) how does a typology scheme contribute to our understanding of the conservation importance of running-water sites or groups of sites? Hungary was selected as a study area because it harbours a biogeographically unique aquatic fauna (Hungarian Lowland Ecoregion; Illies, 1978) and continent-wide projects assessing the conservation value of running waters in Europe using aquatic invertebrates did not include this area (e.g. AQEM, STAR). Consequently, an assessment of this ecoregion with standard methods will contribute to the understanding of the conservation importance of running-water systems in Europe.

\section{Methods}

Study area and running-water typology

Hungary (area: $93,030 \mathrm{~km}^{2}$ ) is partly surrounded by the mountain ranges of the Carpathians and the 
Eastern Alps. Approximately 68\% of the area is situated below an altitude of $200 \mathrm{~m}$ a.s.l. (lowland), and the remaining area is mainly composed of highlands. All running waters belong to the river Danube system.

The official Hungarian typological system for surface waters defines 25 running-water types (Ministry of Environment and Water, 2004). With its large number of river types, this typology is rather complicated and inadequately represents the variability in biodiversity (Hawkins et al., 2000; Heino \& Mykra, 2006; Erős, 2007). Moreover, artificial watercourses are not considered in this typology (Ministry of Environment and Water, 2004), and there is no correspondence between river types and their communities (Ministry of Environment and Water, 2005; van Dam et al., 2007). Therefore, we did not use the official Hungarian typology system. Instead, we applied three criteria (naturalness, altitude and size of catchment area) to classify running waters in Hungary. Running-water sites were classified either as artificial (man-made) or natural. Based on the altitude, running-water sites were assigned to the lowland ( $\leq 200 \mathrm{~m}$ a.s.l.) or highland ( $>200 \mathrm{~m}$ a.s.l.). Based on the size of the catchment area, runningwater sites were assigned to streams (catchment area $\leq 1,000 \mathrm{~km}^{2}$ ) or rivers (catchment area $>1,000 \mathrm{~km}^{2}$ ). In this study, we interpret the term 'running-water type' as the combinations of these three criteria, resulting in eight running-water types (e.g. artificial lowland stream or natural highland rivers). These criteria and the resulting classes correspond to the typology recommended by the Water Framework Directive of the EU, and are also frequently used in bioassessment studies (Hering et al., 2003; Verdonschot \& Nijboer, 2004; Sandin \& Verdonschot, 2006; Fraschetti et al., 2008).

\section{Source of data}

In 2004, the 'Ecological Survey of Surface Waters' program (ECOSURV) was established in Hungary, with the aim to monitor and assess the ecological status of surface waters based on biological (algae, macrophytes, aquatic invertebrates and fish) and hydromorphological- and physico-chemical quality elements (http://www.eu-wfd.info/ecosurv). The project provided a comprehensive, country-wide survey of aquatic invertebrates following the protocol developed in the AQEM project (Hering et al., 2003, 2004). In short, kick and sweep sampling technique was applied at many running-water sites from March 16, 2005 to June 25, 2005 using a hand net (opening: $250 \mathrm{~mm} \times 250 \mathrm{~mm}$, mesh size $0.95 \mathrm{~mm}$; Kiss et al., 2006). In contrast to the AQEM project (Hering et al., 2003, 2004), however, the number of replicate samples was reduced from 20 to 10 , and the sampled material was sorted in the field and not in the laboratory (Kiss et al., 2006). When the habitat structure of a site did not allow the use of the Kick and Sweep technique (e.g. dense aquatic vegetation), then aquatic invertebrates were collected with a net. Ten taxonomic groups (Gastropoda, Bivalvia, Hirudinae, Crustacea, Ephemeroptera, Odonata, Plecoptera, Heteroptera, Coleoptera and Trichoptera) were identified to the possible lowest taxonomic level by specialists (Kiss et al., 2006).

The aquatic invertebrate data from the ECOSURV project were used in this article. We decided to use only presence/absence data to avoid errors as a result of abundance differences caused by different sampling methods (Elliott \& Drake, 1981; Drake \& Elliott, 1982; Blocksom \& Flotemersch, 2005; Cao et al., 2005). We considered only running-water sites and taxa identified to species level. Records with missing data were omitted. A total of 322 sites with presence-absence data from 444 species fulfilled these criteria. However, one running-water type (artificial highland river) did not occur in the ECOSURV project, and the types 'artificial highland stream' and 'artificial lowland river' were represented by only one and four sampling sites, respectively. These running-water types were omitted from the analyses. Consequently, our analyses are based on five running-water types represented by 317 sampling sites (Table 1).

We followed the taxonomical nomenclature of the Fauna Europeae Web Service (2004). Species were classified as non-native (alien) or native based on DAISIE (2008) and on other sources (grey literature). The latter was necessary because some species are alien in Western Europe, but not in Hungary. A total of 20 species $(4.5 \%)$ out of the 444 species were nonnative. Information on red-list species was obtained from the IUCN website (IUCN, 2009). On the IUCN red list three of the 444 species were considered as 'vulnerable' and three as 'near threatened'. Protected species are listed in the corresponding departmental 
Table 1 Overview of running-water types and number of sampling sites used in this study

\begin{tabular}{llllll}
\hline Code & Running-water type & Classification criteria & & $\begin{array}{l}\text { Number of } \\
\text { sampling sites }\end{array}$ \\
\cline { 3 - 5 } & Naturalness & Altitude $(\mathrm{m})$ & Catchment area $\left(\mathrm{km}^{2}\right)$ & $\leq 1000$ & 20 \\
\hline ALS & Artificial lowland stream & Artificial & $\leq 200$ & $>1000$ & 24 \\
NHR & Natural highland river & Natural & $>200$ & $\leq 1000$ & 121 \\
NHS & Natural highland stream & Natural & $>200$ & $>1000$ & 73 \\
NLR & Natural lowland river & Natural & $\leq 200$ & $\leq 1000$ & 79 \\
NLS & Natural lowland stream & Natural & $\leq 200$ & & \\
\hline
\end{tabular}

orders of the Ministry of Environment and Water, Hungary (Ministry of Environment and Water, 2001).

Measures of conservation value and statistical analyses

Species richness of the native invertebrates, number of native unique species, number of red-list species and number of protected species are widely used for measuring the conservation value of sites (Sutherland, 2000). The number of unique species is a complementary measure (Nel et al., 2009), because unique species were defined here as species being present only in the given running-water type. Number of alien species expresses the exposure of river types to invasions. We quantified beta diversity within a running-water type as the average distance (median) of sites to the type centroid as described by Anderson (2006) and Anderson et al. (2006) and used a permutation-based test of multivariate group dispersions (Oksanen et al., 2010).

Linear models with normal (LM) and Generalised Linear Models with Poisson distributions (GLM) were used to test whether site classification criteria reflect species richness of native invertebrates, the numbers of unique native, red-list, protected and alien species; and to examine whether the runningwater types differed in species richness of native invertebrates and in numbers of unique native, redlist, protected and alien species. The minimal adequate model was selected based on Akaike's Information Criterion (AIC). If running-water types showed significant differences, then Tukey multiple comparison of means was applied with 5\% familywise error rate (Zar, 1999). Spearman correlations were used to test for the congruence amongst the measures.
The overall conservation value of each runningwater type was calculated using the following procedure: the mean values of the measures were 'max' transformed (i.e. the mean value of each running-water type was divided by the highest mean value). This step was necessary to make the numerical values of the mean measures comparable, as for instance the highest mean value for the number of native species was 32.55 in artificial lowland stream type, whereas the highest mean value for red-list species was 0.63 in natural lowland river type. We considered this transformed mean values as a conservation value based on the given measures. High mean values represent high conservation values, whereas low mean values express low conservation values with the exception of the number of alien species, where the transformed mean values were multiplied with a numerical value of -1 , following Mouillot et al. (2008). Finally, the conservation values were summed to receive an overall conservation value for each running-water type.

Analysis of similarities (ANOSIM, Clarke, 1993) was performed on the community data to test the community-based separation of running-water types. ANOSIM is a non-parametric multivariate analysis that compares the mean of the ranked similarities within and between running-water types using an $R$ value. $R$ ranges from -1 to +1 . An $R$-value of 1 indicates that all the most similar sites are within the same type. $R=0$ occurs if the high and the low similarity sites are mixed within the running-water types, whereas an $R$-value of -1 indicates that the most similar sites are in different running-water types. ANOSIM was run using Jaccard similarity index (Podani, 2000) with 1,000 permutations to calculate significance values $(P)$. We used the $R$ statistical computing environment (R Development Core Team, 2006) for all analyses. 


\section{Results}

Criterion-based analyses

The minimal adequate model suggests that the number of native species in Hungarian running waters shows sensitivity to the naturalness and altitude of the site and to the interaction between altitude and size of catchment area (Table 2). Sites in artificial watercourses were richer in native species than natural ones, and lowland sites were more species-rich than highland sites (Table 2). The interaction between altitude and the size of the catchment area suggests that the difference reflected by altitude depended on the size of the catchment area: lowland streams were richer in native species than highland streams, whereas highland rivers where more speciesrich than lowland rivers (Table 2; Fig. 1A). Considering the number of unique native species, rivers were more species-rich than streams (Table 2). However, the interaction between the size of the catchment area and altitude indicated that lowland rivers were richer in unique native species than highland rivers, whilst highland streams harboured more unique native species than lowland streams (Table 2; Fig. 1B). The minimal adequate model suggested that the size of the catchment area and altitude reflected differences in the number of red-list species. Rivers and lowland sites maintained a higher number of red-list species than streams and highland sites, respectively (Table 2). Running waters with large catchment area (rivers) maintained a larger number of protected species than running waters with small catchment area (streams; Table 2). The number of alien species showed sensitivity to the altitude, catchment area and their interaction. Lowland sites were more invaded by alien species than highland sites and rivers were more invaded than streams. However, the number of alien species was much higher in lowland rivers than expected on the basis of the main effects (altitude and size of catchment area; Table 2; Fig. 1C).

Typology-based analyses

ANOSIM showed that community patterns of aquatic invertebrates followed the site typology scheme (ANOSIM $R=0.364, P=0.001$ ). Consequently, each type harbours a unique biological assemblage. Sites in different running-water types differed in native species richness $\left(\mathrm{LM}, F_{4,312}=16.664, P<0.001\right)$. The lowest number of native species was found in natural highland streams. Artificial lowland streams and natural lowland streams did not differ in native species richness (Fig. 2A). The running-water types differed in the number of unique native species (GLM with Poisson distribution, $\chi_{4,312}^{2}=35.801, P=$ 0.001). In pairwise comparisons, however, there was only a significant difference between natural lowland rivers and natural lowland streams (Fig. 2B). Runningwater types differed in the number of red-list species (GLM with Poisson distribution, $\chi_{4,312}^{2}=27.019$, $P<0.001)$. Large numbers of red-list species were found in natural lowland rivers, artificial lowland streams and natural highland rivers (Fig. 2C). Natural highland streams and natural lowland rivers harboured only a low number of red-list species. The number of protected species differed between running-water types (GLM with Poisson distribution, $\chi_{4,312}^{2}=$ 62.761, $P<0.001)$. The highest number of protected

Table 2 Effect of river site classification criteria on the measures based on the minimal adequate models selected using AIC

\begin{tabular}{|c|c|c|c|c|c|c|}
\hline $\begin{array}{l}\text { Measure } \\
\text { (number of) }\end{array}$ & Naturalness & Altitude & $\begin{array}{l}\text { Size of } \\
\text { catchment } \\
\text { area }\end{array}$ & $\begin{array}{l}\text { Interaction of altitude } \\
\text { and size of catchment area }\end{array}$ & $\begin{array}{l}\text { Distribution of } \\
\text { the fitted model }\end{array}$ & $\begin{array}{l}\text { Link function of } \\
\text { the fitted model }\end{array}$ \\
\hline Native species & $\mathrm{A}>\mathrm{N}$ & $\mathrm{L}>\mathrm{H}$ & \# & $\mathrm{HR}>\mathrm{LR}$ and $\mathrm{LS}>\mathrm{HS}$ & Normal & Linear \\
\hline Unique native species & - & $\#$ & $\mathrm{R}>\mathrm{S}$ & $\mathrm{LR}>\mathrm{HR}$ and $\mathrm{HS}>\mathrm{LS}$ & Poisson & $\log$ \\
\hline Red-list species & $\#$ & $\mathrm{~L}>\mathrm{H}$ & $\mathrm{R}>\mathrm{S}$ & - & Poisson & $\log$ \\
\hline Protected species & - & $\#$ & $\mathrm{R}>\mathrm{S}$ & - & Poisson & $\log$ \\
\hline Alien species & $\#$ & $\mathrm{~L}>\mathrm{H}$ & $\mathrm{R}>\mathrm{S}$ & $\mathrm{LR}>\mathrm{HR}$ and $\mathrm{LS}>\mathrm{LR}$ & Poisson & $\log$ \\
\hline
\end{tabular}

$A$ artificial, $N$ natural, $H$ highland, $L$ lowland, $R$ river, $S$ stream

\#, criterion was included in the minimal adequate model but its effect was not significant 
Fig. 1 Effect of interactions between altitude and catchment area on the numbers of $\mathbf{A}$ native, $\mathbf{B}$ unique native and $\mathbf{C}$ alien species. Dots show mean values, whiskers standard errors. Streams are indicated by open dots and linked with dashed lines, rivers are indicated by full dots and linked by solid lines
A

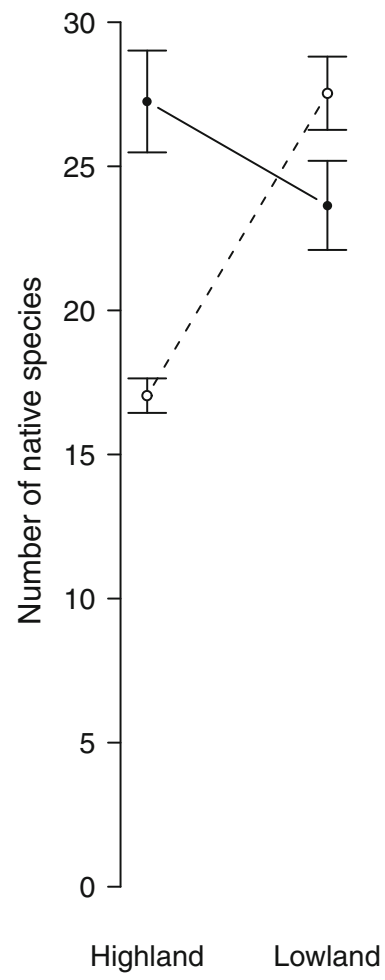

B

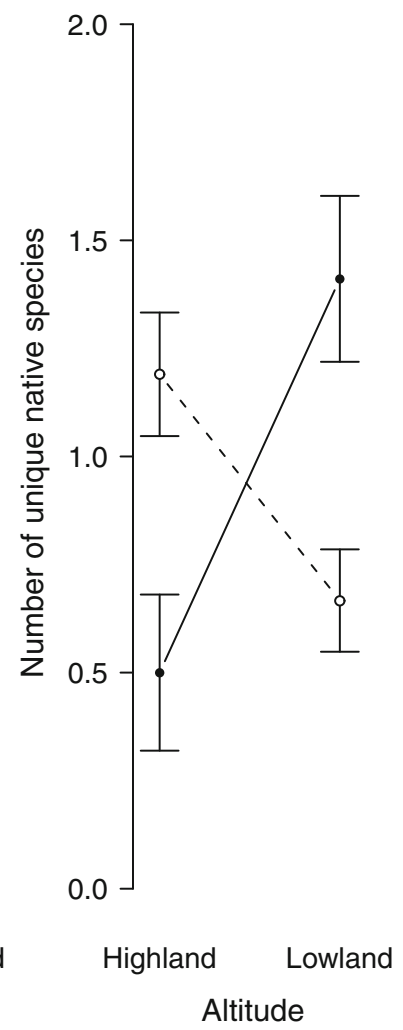

Altitude
C

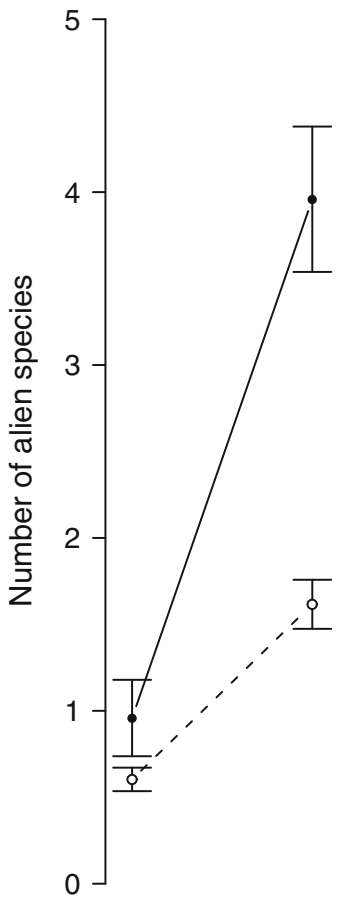

Highland Lowland species was found in natural highland rivers, followed by natural lowland rivers, whereas artificial lowland streams, natural highland streams and natural lowland rivers only contained few protected species. The running-water types differed in the number of alien species (GLM with Poisson distribution, $\chi_{4,312}^{2}=$ 298.520, $P<0.001)$. Large numbers of alien species occurred in artificial lowland streams and natural lowland rivers (Fig. 2D). Running-water types differed in beta diversity (Permutation test for homogeneity of multivariate dispersion $F=15.961$, number of permutations $=999, P<0.001)$. A high beta diversity was recorded in natural highland streams, natural lowland rivers and natural lowland streams, whereas a low beta diversity was found in artificial lowland streams and natural highland rivers (Fig. 3).

The overall conservation values suggest that natural highland rivers are the most valuable running-water types in Hungary, followed by natural lowland rivers, natural highland streams, artificial lowland streams and natural lowland streams (Table 3).
Correlation between conservation measures

Spearman correlation analyses revealed several positive correlations between the different conservation measures (Table 4). Exceptions are the relationship between the number of protected and number of alien species, the relationship between the number of red-list and unique native species, and the relationship between the number of alien and unique native species. The number of native species is correlated with the numbers of unique, red-listed, protected and alien species (Table 4). However, all correlations are relatively low with respect to the large sample size.

\section{Discussion}

Typology is probably the most frequently used approach for assessing conservation values of rivers. In this article, we focused on how criteria of a typology scheme predict the conservation importance of running-water sites in Hungary using conservation 
Fig. 2 The effect of running-water types on the numbers of $\mathbf{A}$ native, $\mathbf{B}$ unique native, $\mathbf{C}$ red-list species, and $\mathbf{D}$ alien species in Hungarian running waters. $A L S$ artificial lowland stream, $N H R$ natural highland river, $N H S$ natural highland stream, $N L R$ natural lowland river, $N L S$ natural lowland stream. Mean values and standard errors are shown. Different letters indicate significant differences between running-water types (Tukey test)

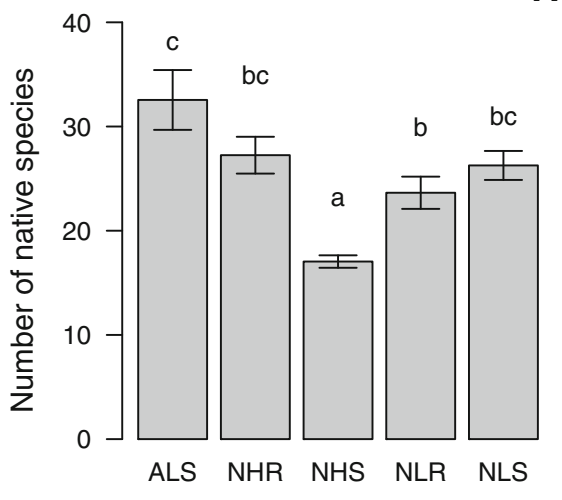

A

B
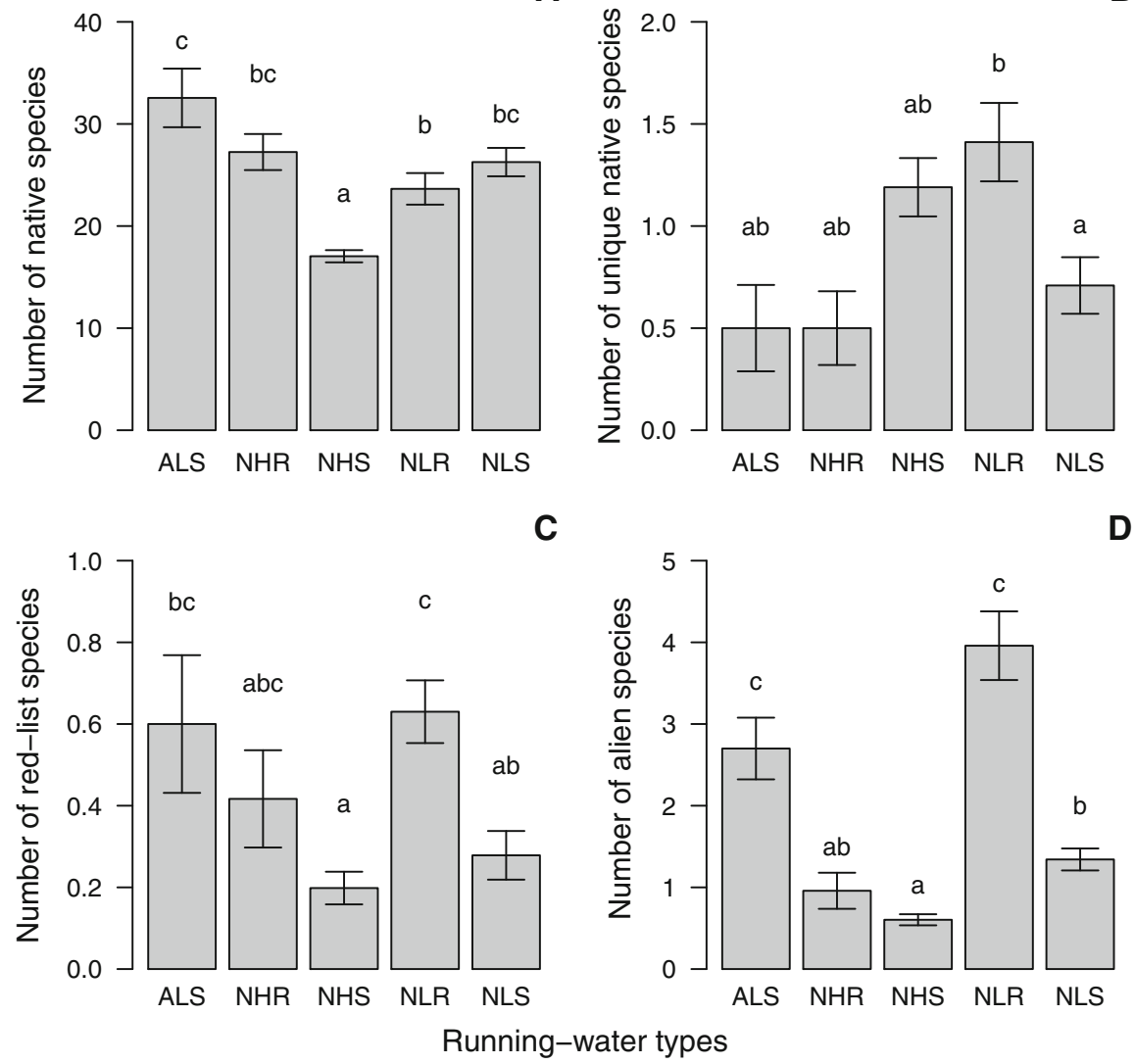

There is increasing evidence that the focus on biodiversity hotspots, nature reserves and protected species does not halt the worldwide biodiversity lost (Le Viol et al., 2009). Instead, there is an urgent need to consider also human-altered and artificial areas in conservation planning and biodiversity management (Edwards \& Abivardi, 1998). There is increasing interest in how artificial habitats contribute to the preservation of species in a country or a region (Brainwood \& Burgin, 2009; Vermonden et al., 2009). We found that artificial watercourses maintain similar conservation values as natural lowland streams. Interestingly, artificial lowland streams harboured numerically the largest number of native species, and also maintained several unique native, red-list and protected species. A possible explanation for the findings could be that aquatic vegetation is often quite abundant in artificial watercourses providing suitable conditions for numerous invertebrate species. This suggests that, from a conservation point of view, artificial watercourses are an integrated part populations. 


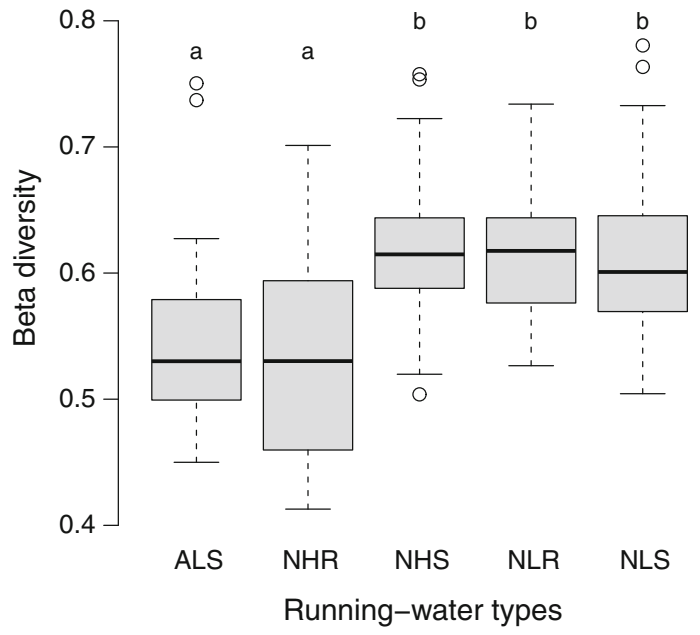

Fig. 3 Effect of running-water types on beta diversity. Beta diversity is measured as the average (median) distance to the type centroid. $A L S$ artificial lowland stream, NHR natural highland river, $N H S$ natural highland stream, NLR natural lowland river, $N L S$ natural lowland stream. Horizontal line shows the median; the bottom and the top of the box the 25th and 75th percentiles, respectively; whiskers show the nonoutlier $\mathrm{max} / \mathrm{min}$ values; circles outliers. Different letters indicate significant differences between running-water types (permutation test)

of the running-water systems in Hungary. As far as we know, this is one of the first studies that compared the conservation value of artificial watercourses with those of natural ones in a country-wide survey.

Introductions of alien species are amongst the most important human impacts on the world's ecosystems (Chapin et al., 2000). In freshwaters, special attention has been paid to the spread, traits and biological effects of alien species (Hekenkamp et al., 2001; Olden \& Poff, 2004; Statzner et al., 2008). Our study did not intend to estimate the spread or the impact of alien species on native communities, but was able to identify the degree of exposure of different river types to alien species. We found that in general rivers and lowland sites are more invaded than streams and highland sites. Possible explanations of this pattern are that rivers are more intensively used by humans than streams and that upstream sites (highland sites) are far away from invasion highways (Vaate et al., 2002; Copp et al., 2005; Dudgeon et al., 2006). Empirical evidences also suggest that some habitat-related conditions might support or restrict the spread of alien species (Schmidlin \& Baur, 2007; Johnson et al., 2008). This might be a possible explanation, why natural lowland rivers and artificial lowland streams were the most exposed running-water types to species invasions.

Assessing conservation value of sites presents a challenge to biologists, mainly due to the effort

Table 3 The conservation value of running-water types in Hungary based on different measures of aquatic invertebrate assemblages

\begin{tabular}{|c|c|c|c|c|c|c|c|}
\hline \multirow{2}{*}{$\begin{array}{l}\text { Running- } \\
\text { water type }\end{array}$} & \multicolumn{6}{|c|}{ Conservation value based on } & \multirow{2}{*}{$\begin{array}{l}\text { Overall } \\
\text { conservation } \\
\text { value }\end{array}$} \\
\hline & $\begin{array}{l}\text { Beta } \\
\text { diversity }\end{array}$ & $\begin{array}{l}\text { Number of } \\
\text { native species }\end{array}$ & $\begin{array}{l}\text { Number of unique } \\
\text { native species }\end{array}$ & $\begin{array}{l}\text { Number of } \\
\text { red-list species }\end{array}$ & $\begin{array}{l}\text { Number of } \\
\text { protected species }\end{array}$ & $\begin{array}{l}\text { Number of } \\
\text { alien species }\end{array}$ & \\
\hline ALS & 0.891 & 1 & 0.354 & 0.952 & 0.249 & -0.682 & 2.764 \\
\hline NHR & 0.864 & 0.837 & 0.354 & 0.661 & 1 & -0.242 & 3.475 \\
\hline NHS & 1 & 0.523 & 0.843 & 0.315 & 0.344 & -0.152 & 2.874 \\
\hline NLR & 0.991 & 0.726 & 1 & 1 & 0.601 & -1 & 3.319 \\
\hline NLS & 0.981 & 0.806 & 0.502 & 0.442 & 0.252 & -0.338 & 2.646 \\
\hline
\end{tabular}

Table 4 Spearman correlation matrix between various conservation measures

\begin{tabular}{llll}
\hline Conservation measure & $\mathrm{S}$ & $\mathrm{U}$ & $\mathrm{R}$ \\
\hline Number of native species (S) & & & $\mathrm{P}$ \\
Number of unique native species (U) & $\mathbf{0 . 2 9 7 * * *}$ & & \\
Number of red-list species (R) & $\mathbf{0 . 3 4 0 * * *}$ & 0.083 & $\mathbf{0 . 1 1 9 *}$ \\
Number of protected species (P) & $\mathbf{0 . 1 6 7 * *}$ & 0.005 & $\mathbf{0 . 3 7 9 *}$ \\
Number of alien species & $\mathbf{0 . 2 9 7 * * *}$ & 0.028 \\
\hline
\end{tabular}

In all cases the sample size is 317 . Significant correlations are in bold. Significance levels are $* P \leq 0.05$, ** $P \leq 0.01$, *** $P \leq 0.001$ 
needed to conduct extensive surveys but also because there is still no agreement on the method to be used (Gascon et al., 2009). Biodiversity-related measures are the most commonly used estimators (Magurran, 1988), but rarity (Schmera, 2003), endangerment status (Brooks et al., 1999), typicalness (Eyre \& Rushton, 1989), endemism (Turpie et al., 2000), functional diversity measures (Schmera et al., 2009) or multimetric indices (Lücke \& Johnson, 2009) are also frequently used. Each measure represents a unique aspect of conservation value and measures are not necessarily correlated (Williams et al., 1996; Schmera, 2003; Wilsey et al., 2005; Heino et al., 2007; Gascon et al., 2009). Therefore, the parallel application of several measures is highly desirable. In the present study, we used six biological measures to express the conservation value of running-water sites and types. We found that most measures were intercorrelated. However, with respect to the relatively large sample size, the correlations were weak. This suggests that each measure represents a unique aspect of conservation value. Consequently, the use of multimetric measures is recommended for conservation assessments. In contrast, other studies showed that the correlation between measures might also be very strong using whole invertebrate communities (Heino et al., 2007, 2008) or single taxa (Schmera, 2003). The positive correlations between the number of alien and native species, and between the number of alien and red-list species suggest that the most valuable sites are threatened by alien species, because synergistic interactions between alien species might negatively influence native communities (Simberloff \& Von Holle, 1999; Baur \& Schmidlin, 2007; Johnson et al., 2009). Thus, our results emphasise the urgent need of actions to protect running waters with conservation values in Hungary.

In our view, the types applied in this study provide a meaningful interpretation of the conservation value of running-water sites in Hungary. Our typology scheme is in accordance with the typology recommended by the Water Framework Directive of the EU and is frequently used in bioassessment studies (Hering et al., 2003; Verdonschot \& Nijboer, 2004; Sandin \& Verdonschot, 2006; Fraschetti et al., 2008). The five running-water types applied here are manageable and comparable to the 29 types used in a Europe-wide study (Verdonschot \& Nijboer, 2004). Moreover, this is the first typology scheme of running-water sites in Hungary that supported the correspondence between site classification and biota (result of ANOSIM) and the first country-wide study that compares the conservation value of runningwater types using aquatic invertebrates in this country. We found that all running-water types are valuable to a certain extent because they maintain distinct biological communities. From another point of view, natural highland rivers are most valuable. This finding is in agreement with another study which showed that Hungarian highland rivers maintain the largest diversity of fish (Erös, 2007). This suggests that conservation management should focus on natural highland rivers in Hungary.

Rivers are amongst the most endangered ecosystems of the world with dramatically decreasing conservation values (Malmqvist \& Rundle, 2002; Dudgeon et al., 2006). Thus, increasing emphasis is being devoted to a critical evaluation of site classification criteria as conservation value indicators of river sites (Heino \& Mykra, 2006). Our results revealed that some criteria used in site typology schemes show interactions with each other, thus the interpretation of their individual effects might be doubtful. However, the findings of this study are essential in maintaining and protecting conservation values of any ecosystem, and may contribute to the management decisions on the running waters in Hungary.

Acknowledgments We would like to thank Zsuzsa Steindl and Andrea Zagyva (Ministry of Environment and Water, Hungary) for allowing access to the ECOSURV database. The work of the people participating in the ECOSURV project is appreciated. We are grateful to Anette Baur, Tibor Erős, Steve Ormerod and two anonymous referees for their comments on the manuscript.

\section{References}

Allan, J. D., 1995. Stream Ecology: Structure and Function of Running Waters. Chapman and Hall, London, UK.

Anderson, M. J., 2006. Distance-based tests for homogeneity of multivariate dispersions. Biometrics 62: 245-253.

Anderson, M. J., K. E. Ellingsen \& B. H. McArdle, 2006. Multivariate dispersion as a measure of beta diversity. Ecology Letters 9: 683-693.

Baur, B. \& S. Schmidlin, 2007. Effects of invasive non-native species on the native biodiversity in the river Rhine. In Nentwing, W. (ed.), Biological Invasions. Ecological Studies, Vol. 193. Springer, Berlin: 257-273. 
Blocksom, K. A. \& J. E. Flotemersch, 2005. Comparison of macroinvertebrate sampling methods for nonwadeable streams. Environmental Monitoring and Assessment 102: 243-262.

Brainwood, M. \& S. Burgin, 2009. Hotspots of biodiversity or homogeneous landscapes? Farms as biodiversity reserves in Australia. Biodiversity and Conservation 18: 3043-3052.

Brooks, T. H., S. L. Pimm, V. Kapos \& C. Ravilious, 1999. Threat from deforestation to mountain and lowland birds and mammals in insular South-East Asia. Journal of Animal Ecology 68: 1061-1076.

Cao, Y., C. P. Hawkins \& A. W. Storey, 2005. A method for measuring the comparability of different sampling methods used in biological surveys: implications for data integration and synthesis. Freshwater Biology 50: 1105-1115.

Chapin, F. S., E. S. Zavaleta, V. T. Eviner, R. S. Naylor, P. M. Vitosek, H. L. Reynolds, D. U. Hooper, S. Lavoler, O. E. Sala, S. E. Hobbie, M. C. Mack \& S. Diaz, 2000. Consequence of changing biodiversity. Nature 405: 234-242.

Clarke, K. R., 1993. Non-parametric multivariate analyses of changes in community structure. Austral Ecology 18: 117-143.

Copp, G. H., P. G. Bianco, N. G. Bogutskaya, T. Erős, I. Falka, M. T. Ferreira, M. G. Fox, J. Freyhof, R. E. Gozlan, J. Grabowska, V. Kovac, R. Moreno-Amich, A. M. Naseka, M. Panaz, M. Povz, M. Przybylski, M. Robillard, I. C. Russell, S. Stakenas, S. Sumer, A. Vila-Gispert \& C. Wiesner, 2005. To be, or not to be, a non-native freshwater fish? Journal of Applied Ichthyology 21: 242-262.

DAISIE, 2008. European Invasive Alien Species Gateway [available on internet at http://www.europe-aliens.org, accessed 26 May 2009].

Drake, C. M. \& M. J. Elliott, 1982. A comparative study of three air-lift samplers used for benthic macro-invertebrates in rivers. Freshwater Biology 12: 511-533.

Dudgeon, D., A. H. Arthington, M. O. Gessner, Z. I. Kawabata, D. J. Knowler, C. Leveque, R. J. Naiman, A. H. PrieurRichard, D. Soto, M. L. J. Stiassny \& C. A. Sullivan, 2006. Freshwater biodiversity: importance, threats, status and conservation challenges. Biological Review 81: $163-182$.

Edwards, P. J. \& C. Abivardi, 1998. The value of biodiversity: where ecology and economy blend. Biological Conservation 83: $239-246$.

Elliott, J. M. \& C. M. Drake, 1981. A comparative study of seven grabs used sampling benthic macroinvertebrates in rivers. Freshwater Biology 11: 99-120.

Erös, T., 2007. Partitioning the diversity of riverine fish: the roles of habitat types and non-native species. Freshwater Biology 52: 1400-1415.

Eyre, M. D. \& S. P. Rushton, 1989. Quantification of conservation criteria using invertebrates. Journal of Applied Ecology 26: 159-171.

Fauna Europaea Web Service, 2004. Fauna Europaea, Version 1.1 [available on internet at http://www.faunaeur.org, accessed 26 May 2009].

Fraschetti, S., A. Terlizzi \& F. Boero, 2008. How many habitats are there in the sea (and where)? Journal of Experimental Marine Biology and Ecology 366: 109-115.
Gascon, S., D. Boix \& J. Sala, 2009. Are different biodiversity metrics related to the same factors? A case study for Mediterranean wetlands. Biological Conservation 142: 2602-2612.

Giller, P. S. \& B. Malmqvist, 1998. The Biology of Streams and Rivers. Oxford University Press, Oxford.

Hawkins, C. P. \& M. R. Vinson, 2000. Weak correspondence between landscape classifications and stream invertebrate assemblages: implications for bioassessment. Journal of the North American Benthological Society 19: 501-517.

Hawkins, C. P., R. H. Norris, J. Gerritsen, R. M. Hughes, S. K. Kackson, R. K. Johnson \& R. J. Stevenson, 2000. Evaluating of the use of landscape classifications for prediction of freshwater biota: synthesis and recommendations. Journal of the North American Benthological Society 19: 541-556.

Heino, J. \& H. Mykra, 2006. Assessing physical surrogates for biodiversity: do tributary and stream type classifications reflect macroinvertebrate assemblage diversity in running waters? Biological Conservation 129: 418-426.

Heino, J., H. Mykra, H. Hamalainen, J. Aroviita \& T. Muotka, 2007. Responses of taxonomic distinctness and species diversity indices to anthropogenic impacts and natural environmental gradients in stream macroinvertebrates. Freshwater Biology 52: 1846-1861.

Heino, J., H. Mykra \& J. Kotanen, 2008. Weak relationship between landscape characteristics and multiple facets of stream macroinvertebrate biodiversity in a boreal drainage basin. Landscape Ecology 23: 417-426.

Hekenkamp, C. C., S. G. Ribblett, M. A. Palmer, C. M. Swan, J. W. Reid \& M. R. Goodison, 2001. The impact of an introduced bivalve (Corbicula fluminea) on the benthos of a sandy stream. Freshwater Biology 46: 491-501.

Hering, D., A. Buffagni, O. Moog, L. Sandin, M. Sommerhauser, I. Stubauer, C. Feld, R. Johnson, P. Pinto, N. Skoulikidis, P. Verdonschot \& S. Zahradkova, 2003. The development of a system to assess the ecological quality of streams based on macroinvertebrates-design of the sampling, programme with the AQEM project. International Review of Hydrobiology 88: 345-361.

Hering, D., O. Moog, L. Sandin \& P. F. M. Verdonschot, 2004. Overview and application of the AQEM assessment system. Hydrobiologia 516: 1-20.

Higgins, J. V., M. T. Bryer, M. L. Khoury \& T. W. Fitzhugh, 2004. A freshwater classification approach for biodiversity conservation planning. Conservation Biology 19: 432-445.

Hynes, H. B. H., 1970. The Ecology of Running Waters. Liverpool University Press, Liverpool, UK.

Illies, J. (ed.), 1978. Limnofauna Europea. Gustav Fischer Verlag, Stuttgart, Germany.

IUCN, 2009. IUCN Red List of Threatened Species, Version 2009.1 [available on internet at www.iucnredlist.org, accessed 24 June 2009].

Johnson, P. T. J., J. D. Olden \& M. J. V. Zaden, 2008. Dam invaders: impoundments facilitate biological invasions into freshwaters. Frontiers in Ecology and Environment 6: 357-363.

Johnson, P. T. J., J. D. Olden, C. T. Solomon \& M. J. V. Zanden, 2009. Interactions among invaders: community and ecosystem effects of multiple invasive species in an experimental aquatic system. Oecologia 159: 161-170. 
Karr, J. R., L. A. Toth \& D. R. Dudley, 1985. Fish communities of Midwestern rivers: a history of degradation. BioScience 35: 90-95.

Kiss, B., P. Juhász, Z. Müller, L. Nagy \& Á. Gáspár, 2006. Summary of the Ecological Survey of Surface Waters of Hungary (ECOSURV) (sampling locations, methods and investigators). Folia Historico Naturalia Musei Matraensis 30: 299-304.

Le Viol, I., J. Mocq, R. Julliard \& C. Kerbiriou, 2009. The contribution of motorway stormwater retention ponds to the biodiversity of aquatic macroinvertebrates. Biological Conservation 142: 3163-3171.

Lücke, J. D. \& R. K. Johnson, 2009. Detection of ecological change in stream macroinvertebrate communities using single metric, multimetric or multivariate approaches. Ecological Indicators 9: 659-669.

Magurran, E., 1988. Ecological Diversity and its Measurement. Crom Helm, London.

Malmqvist, B. \& S. Rundle, 2002. Threats to the running to the running water ecosystems of the world. Environmental Conservation 29: 134-153.

Ministry of Environment and Water, 2001. Departmental Order 13/2001 (V.9.) on the Protected Species in Hungary.

Ministry of Environment and Water, 2004. Departmental Order 31/2004 (XII. 30.) on the Rules of Assessment and Evaluation of Surface Waters in Hungary.

Ministry of Environment and Water, 2005. ECOSURV. BQE Reports Macro-invertebrates [available on internet at http://www.eu-wfd.info/ecosurv/, assessed 10 October 2009].

Moilanen, A., J. Leathwick \& J. Elith, 2008. A method for spatial freshwater conservation prioritization. Freshwater Biology 53: 577-592.

Mouillot, D., J. M. Culioi, D. Pelletier \& J. A. Tomasini, 2008. Do we protect biological originality in protected areas? A new index and an application to the Bonifacio Strait Natural Reserve. Biological Conservation 141: 1569-1680.

Nel, J. L., D. J. Roux, R. Abell, P. J. Ashton, R. M. Cowling, J. V. Higgins, M. Thieme \& H. J. Viers, 2009. Progress and challenges in freshwater conservation planning. Aquatic Conservation: Marine and Freshwater Ecosystems 19: 474-485.

Newson, M. D., M. J. Clark, D. A. Sear \& A. Brookes, 1998. The geomorphological basis of classifying rivers. Aquatic Conservation: Marine and Freshwater Ecosystems 8: 415-430.

Oksanen J., F. G. Blanchet, R. Kindt, P. Legendre, R. B. O'Hara, G. L. Simpson, P. Solymos, M. H. H. Stevens \& H. Wagner, 2010. Vegan: Community Ecology Package. R Package Version 1.17-4 [available on internet at http://CRAN.R-project.org/package=vegan].

Olden, J. D. \& N. L. Poff, 2004. Ecological processes driving biotic homogenization: testing a mechanistic model using fish faunas. Ecology 85: 1867-1875.

Ormerod, S. J., 2009. Climate change, river conservation and the adaptation challenge. Aquatic Conservation: Marine and Freshwater Ecosystems 19: 609-613.

Podani, J., 2000. Introduction into the Exploration of Multivariate Biological Data. Backhuys Publishers, Leiden, The Netherlands.
Poff, N. L., D. Allan, M. B. Bain, J. R. Karr, K. L. Prestegaard, B. D. Richter, R. E. Sparks \& J. C. Stromberg, 1997. The natural flow regime. A paradigm of river conservation and restoration. BioScience 47: 769-784.

Pyne, M. I., R. B. Rader \& W. F. Christensen, 2007. Predicting local biological characteristics in streams: a comparison of landscape classifications. Freshwater Biology 52: 1302-1321.

Rabeni, F. R., K. E. Doisy \& D. L. Galat, 2002. Testing the biological basis of a stream habitat classification using benthic invertebrates. Ecological Applications 12: 782-796.

R Development Core Team, 2006. R: A Language and Environment for Statistical Computing. R Foundation for Statistical Computing, Vienna [available on internet at http://www.R-project.org].

Sandin, L. \& P. F. M. Verdonschot, 2006. Stream and river typologies-major results and conclusions from the STAR project. Hydrobiologia 566: 33-37.

Schmera, D., 2003. Assessing stream dwelling caddisfly assemblages (Insecta: Trichoptera) collected by light traps in Hungary. Biodiversity and Conservation 12: 1175-1191.

Schmera, D. \& O. Kiss, 2004. A new measure of conservation value combining rarity and ecological diversity: a case study with light trap collected caddisflies (Insecta: Trichoptera). Acta Zoologica Academiae Scientiarum Hungaricae 50: 195-210.

Schmera, D., T. Erős \& J. Podani, 2009. A measure for assessing functional diversity in ecological communities. Aquatic Ecology 43: 157-167.

Schmidlin, S. \& B. Baur, 2007. Distribution and substrate preference of the invasive clam Corbicula fluminea in the river Rhine in the region of Basel (Switzerland, Germany, France). Aquatic Sciences 69: 153-161.

Simberloff, D. \& B. Von Holle, 1999. Positive interactions of nonindigenous species: invasional meltdown? Biological Invasions 1: 21-32.

Statzner, B., N. Bonada \& S. Doledec, 2008. Biological attributes discriminating invasive from native European stream macroinvertebrates. Biological Invasions 10: 517-530.

Sutherland, W. J., 2000. The Conservation Handbook: Research, Management and Policy. Blackwell Science, Oxford.

Townsend, C. R., 1989. The patch dynamics concept of stream community ecology. Journal of the North American Benthological Society 8: 36-50.

Townsend, C. R. \& A. G. Hildrew, 1994. Species traits in relation to a habitat templet for river systems. Freshwater Biology 31: 265-275.

Turpie, J. K., L. E. Beckley \& S. M. Katua, 2000. Biogeography and the selection of priority areas for conservation of South African coastal fishes. Biological Conservation 92: 59-72.

Vaate, A. B. D., K. Jazdezewski, H. A. M. Ketelaars, S. Gollasch \& G. V. D. Velde, 2002. Geographical patterns in range extension of Ponto-Caspian macroinvertebrate species in Europe. Canadian Journal of Fisheries and Aquatic Sciences 59: 1159-1174. 
van Dam, H., C. Stenger-Kovács, É. Ács, G. Borics, K. Buczkó, É. Hajnal, É. Soróczki-Pintér, G. Várbiró, B. Tóthmérész \& J. Padisák, 2007. Implementation of the European Water Framework Directive: Development of a system for water quality assessment of Hungarian running waters with diatoms. Archiv für Hydrobiologie Supplement Large Rivers 17: 365-382.

Verdonschot, P. F. M. \& R. C. Nijboer, 2004. Testing the European typology of the Water Framework Directive for macroinvertebrates. Hydrobiologia 516: 35-54.

Vermonden, K., R. S. E. W. Leuven, G. van der Velde, M. M. van Katwijk, J. G. M. Roelofs \& A. J. Hendriks, 2009. Urban drainage systems: an undervalued habitat for aquatic macroinvertebrates. Biological Conservation 142: 1105-1115.

Ward, J. V., 1989. The four-dimensional nature of lotic ecosystems. Journal of the North American Benthological Society 8: 2-8.

Williams, P., D. Gibbons, C. Margules, A. Rebelo, C. Humphries \& R. Pressey, 1996. A comparison of richness hotspots, rarity hotspots and complementary areas for conserving diversity of British birds. Conservation Biology 10: 155-174.

Williams, P., M. Whitfield, J. Biggs, S. Bray, G. Fox, P. Nicolet \& D. Sear, 2003. Comparative biodiversity of rivers, streams, ditches and ponds in an agricultural landscape in Southern England. Biological Conservation 115: 329-341.

Wilsey, B. J., D. R. Chalcraft, C. M. Bowles \& M. R. Willig, 2005. Relationships between indices suggest that richness is an incomplete surrogate for grassland biodiversity. Ecology 86: 1178-1184.

Wirth, A., D. Schmera \& B. Baur, 2010. Native and alien macroinvertebrate richness in a remnant of the former river Rhine: a source for recolonisation of restored habitats? Hydrobiologia 652: 89-100.

Zar, J. H., 1999. Biostatistical Analysis, 4th ed. Prentice-Hall, New Jersey. 